\title{
Nutrient Value of Leaf vs. Seed
}

\author{
Marvin Edelman ${ }^{1 *}$ and Monica Colt ${ }^{2}$ \\ ${ }^{1}$ Department Plant and Environmental Sciences, Weizmann Institute of Science, Rehovot, Israel, ${ }^{2}$ Hinoman Ltd., Or Yehuda, \\ Israel
}

Major differences stand out between edible leaves and seeds in protein quality, vitamin, and mineral concentrations and omega 6/omega 3 fatty acid ratios. Data for seeds (wheat, rice, corn, soy, lentil, chick pea) are compared with corresponding data for edible green leaves (kale, spinach, broccoli, duckweed). An x/y representation of data for lysine and methionine content highlights the group differences between grains, pulses, leafy vegetables, and animal foods. Leaves come out with flying colors in all these comparisons. The perspective ends with a discussion on "So why do we eat mainly seeds?"

Keywords: leaf protein, leaf vitamins, leaf minerals, omega 6/3 ratio, duckweed

\section{LEAF VS. SEED PROTEIN}

\section{OPEN ACCESS}

Edited by:

Bharat B. B. Chattoo,

M.S. University of Baroda, India

Reviewed by:

Giovanna Frugis,

National Research Council, Italy

Bhavneet Kaur,

Agricultural Research Service - United

States Department of

Agriculture/Purdue University, USA

*Correspondence:

Marvin Edelman

marvin.edelman@weizmann.ac.il

Specialty section:

This article was submitted to Agricultural Biological Chemistry, a section of the journal

Frontiers in Chemistry

Received: 08 March 2016

Accepted: 07 July 2016

Published: 21 July 2016

Citation:

Edelman M and Colt M (2016) Nutrient Value of Leaf vs. Seed.

Front. Chem. 4:32.

doi: 10.3389/fchem.2016.00032
There is a significant difference between seed protein and leaf protein. Seeds (grains and legume pulses) are in the business of plant reproduction and nurturing the developing plant. Leaves, on the other hand, deal mainly with photosynthesis in the mature plant, a process of harnessing visible radiance to produce carbohydrates, and biochemical energy.

Seed protein is a composite of hundreds of different enzymes and structural proteins (Yang et al., 2013), however, its protein complement is dominated by a family of storage proteins: In corn kernels its zein, which comprises up to $60 \%$ of the endosperm protein (Larkins and Holding, 2009); in wheat grains its glutenins, which accounts for $40 \%$ of the grain protein (Liu et al., 2012); in the rice grain its glutelins, which comprise over $80 \%$ of the seed protein (Shyur et al., 1988).

Storage protein imparts individuality to the seed grain: The insolubility of zein in water (Shukla and Cheryan, 2001), the elasticity of glutenin in dough (Kieffer, 2006), the gelling of glutelin in rice (Agboola et al., 2005). However, along with individuality, an imbalance in nutritional composition often crops up. Many seeds are deficient in one or more of the essential amino acids that our bodies cannot synthesize and which we obtain solely from food intake. For example, several cereal grains are deficient in lysine and tryptophan, while legume pulses are often deficient in methionine and/or cysteine (Shewry et al., 1995; Figure 1A).

The general difference in amino acid composition among the grains, legumes, and leafy vegetables can readily be visualized by comparing methionine and lysine values (Figure 1B). The grains and most other monocot food plants are generally poor in lysine (see the boxed positions for wheat, corn, and rice), while the dicot legume pulses are often lacking in methionine (see the boxed positions for soy, chickpea, and lentil). Leafy vegetables on the other hand (see boxed positions for spinach, broccoli, and duckweed) edge into the FAO standard quadrant along with the animal foods.

Leaf protein is likewise composed of hundreds of enzymes and is likewise dominated by a single polypeptide complex: RUBISCO (ribulose 1,5-bisphosphate carboxylase/oxygenase), which is a crucial component in the photosynthetic fixation of atmospheric carbon within green plants. RUBISCO (previously known as Fraction 1 protein), is located in leaf chloroplasts and can account for $50 \%$ of total leaf cell protein (Kawashima and Wildman, 1970). In some plants, RUBISCO 
A Essential amino acids $b$

\begin{tabular}{|c|c|c|c|c|c|c|c|c|c|}
\hline \multirow{3}{*}{$\%$} & \multicolumn{6}{|c|}{ Seed } & \multirow{2}{*}{\multicolumn{3}{|c|}{ Leaf }} \\
\hline & \multicolumn{3}{|c|}{ Grain } & \multicolumn{3}{|c|}{ Legume } & & & \\
\hline & Wheat & Corn & Rice & Soy & $\begin{array}{c}\text { Chick } \\
\text { pea }\end{array}$ & Lentil & Spinach & Broccoli & $\begin{array}{l}\text { Duck } \\
\text {-weed }\end{array}$ \\
\hline Tryptophan & 1.3 & 0.1 & 1.2 & 1.4 & 1.0 & 1.0 & 1.6 & 1.8 & 2.0 \\
\hline Threonine & 2.7 & 3.8 & 3.6 & 4.1 & 3.8 & 3.9 & 4.9 & 3.9 & 5.0 \\
\hline Isoleucine & 3.9 & 3.6 & 4.3 & 4.6 & 4.5 & 4.7 & 5.9 & 3.9 & 4.5 \\
\hline Leucine & 6.8 & 12.3 & 8.3 & 7.7 & 7.4 & 7.9 & 8.9 & 6.3 & 9.0 \\
\hline Lysine & 2.2 & 2.8 & 3.6 & 6.3 & 6.9 & 7.6 & 7.0 & 7.4 & 6.5 \\
\hline Methionine & 1.6 & 2.1 & 2.3 & 1.3 & 1.4 & 0.9 & 2.1 & 1.8 & 2.1 \\
\hline Phenylalanine & 5.0 & 4.9 & 5.3 & 4.9 & 5.6 & 5.4 & 5.2 & 4.8 & 5.8 \\
\hline Valine & 4.4 & 5.1 & 6.1 & 4.7 & 4.3 & 5.4 & 6.5 & 5.7 & 5.9 \\
\hline Histidine & 2.4 & 3.1 & 2.3 & 2.6 & 2.9 & 3.1 & 2.6 & 2.5 & 2.2 \\
\hline
\end{tabular}

B Methionine versus lysine content in plant and animal protein ${ }^{\mathrm{c}}$

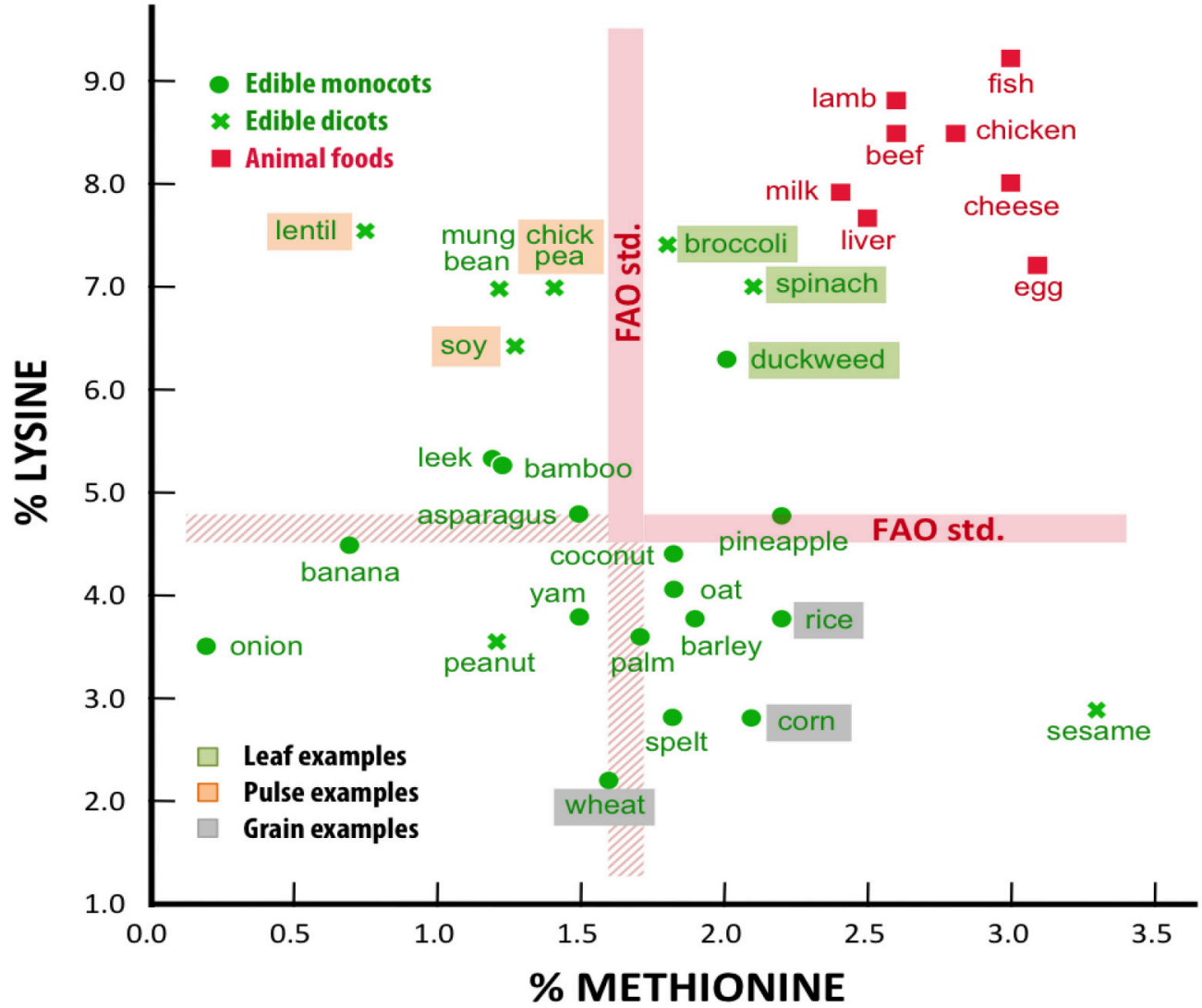

FIGURE 1 | Essential amino acids compositions for some seed and leafy plants ${ }^{\mathrm{a}}$. (A) Essential amino acids ${ }^{\mathrm{b}}$. (B) Methionine vs. lysine content in plant and animal protein ${ }^{\mathrm{C}}$. aValues calculated as percent of total amino acids. Data for dried duckweed were determined by Eurofins USA for a local Israeli isolate of Wolffia sp. Data for all other plants were abstracted from http://nutritiondata.self.com and are based on USDA National Nutrient Database for Standard Reference (http://ndb.nal. usda.gov/ndb/foods). bAll values meet WHO/FAO minimal adult indispensable amino acid requirements (WHO technical Report Series 935, 2007), except for values in red. "The thickness of the FAO standard lines is due to different requirements for "adults" and "children and adolescents" (WHO Technical Report Series 935, 2007). The range varies, respectively, from 1.6 to 1.7 for Methionine and 4.5 to 4.8 for Lysine. 
TABLE 1 | Nutritional compositions for some seed and leafy plants ${ }^{a}$.

\begin{tabular}{|c|c|c|c|c|c|c|c|c|}
\hline & \multicolumn{5}{|c|}{ Seed } & \multicolumn{3}{|c|}{ Leaf } \\
\hline & Wheat & Corn & Rice & Soy & Lentil & Kale & Spinach & Duck-weed \\
\hline \multicolumn{9}{|c|}{ A. VITAMIN CONCENTRATIONS ${ }^{b}$} \\
\hline Vitamin A, IU (beta-carotene) & 9 & 167 & 0 & 114 & 68 & 130,000 & 85,500 & 77,900 \\
\hline Vitamin B1, mg (thiamine) & 0.4 & 0.2 & 0.2 & 0.6 & 0.6 & 0.9 & 0.9 & 1.1 \\
\hline Vitamin B2, mg (riboflavin) & 0.2 & 0.1 & 0 & 1.1 & 1.3 & 0.9 & 1.8 & 2.8 \\
\hline Vitamin B5, mg (pantothenate) & 1 & 0.5 & 1.5 & 1.5 & 0.4 & 0.9 & 0.9 & 2.1 \\
\hline Vitamin B6, mg (pyridoxal) & 0.3 & 0.3 & 0.8 & 0.5 & 0.5 & 2.5 & 1.8 & 1 \\
\hline Vitamin C, mg (ascorbic acid) & 0 & 0 & 0 & 0 & 2 & 1014 & 256 & 94 \\
\hline Vitamin E, mg (tocopherols) & 0.8 & 0.3 & 0.2 & 1.8 & - & 9.3 & 18.2 & 45.7 \\
\hline Vitamin K1, $\mu \mathrm{g}$ (phylloquinone) & 1.9 & 0.2 & 0 & 67 & - & 6900 & 4400 & 51 \\
\hline \multicolumn{9}{|c|}{ B. MINERAL CONCENTRATIONS ${ }^{b}$} \\
\hline Calcium, mg & 34 & 6.4 & 10 & 195 & 34 & 846 & 1036 & 607 \\
\hline Iron, mg & 3.8 & 2.2 & 0.4 & 6 & 6.4 & 8.3 & 28.4 & 25.7 \\
\hline Magnesium, mg & 120 & 85 & 36 & 407 & 46 & 265 & 827 & 231 \\
\hline Phosphorus, mg & 332 & 250 & 100 & 469 & 276 & 519 & 513 & 1741 \\
\hline Potassium, mg & 405 & 289 & 78 & 2387 & 664 & 2769 & 5840 & 5319 \\
\hline Sodium, mg & 3.1 & 4.6 & 0 & 12.3 & 5.9 & 214 & 827 & 132 \\
\hline Zinc, mg & 3 & 1.6 & 0.8 & 3.7 & 3.2 & 3.2 & 5.5 & 15 \\
\hline \multicolumn{9}{|c|}{ C. OMEGA-6/OMEGA-3 FATTY ACID RATIO } \\
\hline$\omega-6 / \omega-3$ & 19.4 & 32.2 & 4.7 & 7.5 & 3.7 & 0.8 & 0.2 & 0.3 \\
\hline
\end{tabular}

${ }^{a}$ Derived from the USDA National Nutrient Database (http://nutritiondata.self.com) for: Wheat flour, whole grain; corn flour, whole grain, yellow; rice flour, white, unenriched; soy flour, full-fat, raw; chick pea, mature seeds, raw; lentil, pink, raw; spinach, raw; broccoli, raw; kale, raw. Data for duckweed determined by Eurofins USA for a local Israeli isolate of dried, raw, Wolffia sp.

${ }^{b}$ Values are per $100 \mathrm{~g}$ sample. All samples normalized to $10 \%$ moisture. "-" indicates a missing or incomplete value.

even crystallizes within the leaf due to its high concentration (Willison and Davey, 1976). Many chloroplast proteins, including RUBISCO, are highly conserved at the gene and protein levels (Sane and Amla, 1991). Thus, RUBISCO is pretty much the same protein in all green leafy plants, with only a few amino acids changes from species to species.

Importantly, RUBISCO is rich in the essential amino acids, with usually eight of the designated nine at percentages meeting FAO (Food and Agricultural Organization of the United Nations) nutritional criteria (Kung and Tso, 1978). Leafy plants such as spinach, broccoli, and duckweed (a monocot plant consisting of nothing much more than a single leaf), in fact provide protein containing all the essential amino acids in percentages meeting FAO standards (Figure 1A). In order to achieve a fully nutritional state, seed protein often needs to be a mix of several sources; for example, the famous combination of sesame seeds (tahini) rich in methionine but poor in lysine, with chickpeas (humus), rich in lysine but poor in methionine (Figure 1B).

\section{VITAMINS IN LEAVES AND SEEDS}

Vitamins are essential nutrients required in small amounts that our bodies are not able to supply in sufficient quantity. Therefore, they must be obtained from the foods we eat. The complement of vitamins in leaves and seeds are very different. Grains are generally low in vitamins, legume pulses are spotty (for example, green pea is rich in vitamin $\mathrm{C}$ but not in other vitamins) while leafy vegetables are often rich in several vitamins. This can be readily seen by comparing vitamin concentrations for green leafy vegetables with comparable data for grains and pulses in USDA's National Nutrient Database (Nutritiondata Tools, 2014). Edible green leaves, including duckweed (Landolt and Kandeler, 1987; Marizvikuru and Gwaze, 2013), generally have at least an order of magnitude more pro-vitamin A (i.e., beta-carotene), vitamin $\mathrm{B} 1$ (thiamine), vitamin $\mathrm{C}$ (ascorbic acid), vitamin $\mathrm{E}$ (alpha tocopherol), and vitamin $\mathrm{K}$ (naphthoquinones) than do grains or pulses (Table 1A).

\section{MINERALS IN LEAVES AND SEEDS}

Metal ions are crucial for our body. They frequently serve as cofactors in enzymatic reactions and are also important for maintaining protein structure. A third of human proteins bind metal ions, with over $10 \%$ of enzymes in our body requiring zinc for activity (Azia et al., 2015). The comparative metal ion profile for leaves and seeds is reminiscent of that for vitamins. Grains such as wheat, rice, and corn are relatively low in metal ions, legume pulses such as soy have increased amounts of several minerals, while green leafy vegetables such as kale, spinach, and duckweed (Feedipedia, 2013) are richer in many minerals (Table 1B).

There is a caveat, however, when considering metal ion data. While the amino acid composition (Atanasova, 2008) and the vitamin profile (Mozafar, 1993) of edible plants can be somewhat influenced by the fertility of the soil or the water 
in which they are growing, the metal ion composition is often more responsive (Macnair, 2003; Chibuike and Obiora, 2014). Water plants such as duckweed are particularly responsive to metal concentrations in their nutrient medium (Wang, 1990). The upshot is, metal ion concentrations quoted for leaves and seeds are, to a large extent, specific for the conditions of fertilization.

\section{OMEGA-6 VS. OMEGA-3 FATTY ACIDS IN LEAVES AND SEEDS}

Current research indicates that an excess of omega- 6 fatty acids in our diets can promote prothrombotic and proaggregatory activity, while omega-3 fatty acids promote an anti-inflammatory and anti-thrombotic physiology (Simopoulos, 2002, 2006). There is, in general (with exceptions, such as chia seeds (Nutritiondata Products, 2014), a stark difference between seed and leaf fatty acid compositions. While the former are high in omega- 6 , the latter are high in omega-3 (Table $1 \mathrm{C}$ ). In addition, $\alpha$-linolenic acid, which is abundant in many green leafy vegetables and is a major source of omega-3, can metabolize in our bodies to longer chain fatty acids such as eicosapentaenoic acid, and docosahexaenoic acid. These in turn may beneficially affect chronic disease control (Simopoulos, 2002).

\section{SO WHY DO WE EAT MAINLY SEEDS?}

The major portion of the calories in Western and many other diets comes from seeds and seed products, particularly from a very narrow field of four sources: wheat, rice, corn, and soy. The recent, huge increase in the use of soy oil, with its biased linoleic acid/ $\alpha$-linolenic acid ratio, has in fact driven a change in the omega-6/omega-3 ratio from $\sim 1: 1$ to $\sim 10-30: 1$ in the American population (Blasbalg et al., 2011), a change which may impact negatively on several health aspects (Simopoulos, 2002, 2006). Why if the nutrition value is so clearly on the side of leaves

\section{REFERENCES}

Agboola, S., Ng, D., and Mills, D. (2005). Characterization and functional properties of Australian rice protein isolates. J. Cereal Sci. 41, 283-290. doi: 10.1016/j.jcs.2004.10.007

Aletor, V. A., and Adeogun, O. A. (1995). Nutrient and anti-nutrient components of some tropical leafy vegetables. Food Chem. 53, 375-379. doi: 10.1016/03088146(95)99830-S

Atanasova, E. (2008). Effect of nitrogen sources on the nitrogenous forms and accumulation of amino acid in head cabbage. Plant Soil Environ. 54, 66-71.

Azia, A., Levy, R., Unger, R., Edelman, M., and Sobolev, V. (2015). Genomewide computational determination of the human metalloproteome. Proteins 83, 931-939. doi: 10.1002/prot.24790

Blasbalg, T. L., Hibbeln, J. R., Ramsden, C. E., Majchrzak, S. F., and Rawlings, R. R. (2011). Changes in consumption of omega- 3 and omega- 6 fatty acids in the United States during the 20th century. Am. J. Clin. Nutr. 93, 950-962. doi: 10.3945/ajcn.110.006643

Chibuike, G. U., and Obiora, S. C. (2014). Heavy metal polluted soils: effect on plants and bioremediation methods. Appl. Environ. Soil Sci. 2014:752708. doi: $10.1155 / 2014 / 752708$ do we feed mainly on potentially problematic seeds and seed products?

The answer seems to lie partly with intrinsic biological issues and partly with big business practice. Roughly speaking, wheat and rice grains, corn kernels, and soybeans are harvested at moisture levels between 15 and 25\% (see statistics, Nutritiondata Tools, 2014), while fresh, edible green leaves, such as spinach, broccoli, lettuce, and duckweed each have a moisture level of >90\% (see statistics, Landolt and Kandeler, 1987; Nutritiondata Tools, 2014). Therefore, to capture equal amounts of solids, one has to consume about four to six times more leaves than seeds, grains, or beans. An additional factor is oxalate, which has antinutrient activity and is prevalent in leafy vegetables (Aletor and Adeogun, 1995). However, in this regard, seeds have their own Achilles heel in the form of anti-nutritional allergens (Taylor et al., 2015).

External factors are also at play: Commercial seed crops are adept at production of carbohydrates, oils, and proteins. Increasingly used as feed, they are efficiently transmuted into animal protein and processed food products. Moreover, with massive silo storage, grains function as international commercial commodities (Pollan, 2007). In the case of soy beans, an increased demand for soy protein for industrial production of beef and chicken led to an excess of soy oil as a byproduct, which quickly became a food staple for restaurants, and the fast food industry (Blasbalg et al., 2011).

With a growing awareness of health issues generated by seed dominated diets, and the documented abundance of nutrients in leafy vegetables, a move in the West appears to be developing back to leaf-based foods and, importantly, to an increased variety of plant species decorating our meal plate.

\section{AUTHOR CONTRIBUTIONS}

ME conceived and wrote the article. MC grew and prepared the Wolffia samples for analysis and assisted in the construction of Table 1.

Feedipedia, (2013). Duckweed, Dried. Available online at: http://www.feedipedia. org/node/15722

Kawashima, N., and Wildman, S. G. (1970). Fraction 1 protein. Annu. Rev. Plant Physiol. 21, 325-358. doi: 10.1146/annurev.pp.21.060170.001545

Kieffer, R. (2006). "The role of gluten elasticity in the baking quality of wheat," in Future of Flour-A Compendium of Flour Improvement, eds L. Popper, W. Schäfer, and W. Freund (Clenze: Verlag Agrimedia), 169178.

Kung, S. D., and Tso, T. C. (1978). Tobacco as a potential food source and smoke material: soluble protein content, extraction, and amino acid composition. J. Food Sci. 43, 1844-1852. doi: 10.1111/j.1365-2621.1978.tb07428.x

Landolt, E., and Kandeler, R. (1987). The Family of Lemnaceae - A Monographic Study, Vol. 2. Stiftung Ruebel: Veroeffentlichungen des Geobotanischen Institutes der ETH.

Larkins, B. A., and Holding, D. R. (2009). "Zein storage proteins," in Molecular Genetic Approaches to Maize Improvement, eds A. L. Kriz and B. A. Larkins (Berlin; Heidelberg: Springer-Verlag), 269-286.

Liu, W., Zhang, Y., Gao, X., Wang, K., Wang, S., Zhang, Y., et al. (2012). Comparative proteome analysis of glutenin synthesis and accumulation in developing grains between superior and poor quality bread wheat cultivars. J. Sci. Food Agric. 92, 106-115. doi: 10.1002/jsfa.4548 
Macnair, M. R. (2003). The hyperaccumulation of metals by plants. Adv. Bot. Res. 40, 63-105. doi: 10.1016/S0065-2296(05)40002-6

Marizvikuru, M., and Gwaze, F. R. (2013). Characteristics of duckweed and its potential as feed source for chickens reared for meat production: a review. Acad. J. 8, 689-697. doi: 10.5897/SREX12.003

Mozafar, A. (1993). Nitrogen fertilizers and the amount of vitamins in plants: a review. J. Plant Nutr. 16, 2479-2506. doi: 10.1080/019041693 09364698

Nutritiondata Products (2014). Chia Seeds, Dried. Available online at: http:// nutritiondata.self.com/facts/nut-and-seed-products/3061/2

Nutritiondata Tools (2014). Available online at: http://nutritiondata.self.com/ tools/nutrient-search

Pollan, M. (2007, January 28). Unhappy meals. The New York Times Magazine.

Sane, P. V., and Amla, D. V. (1991). "Genetics of photosynthesis components," in Biochemical Aspects of Crop Improvement, ed K. R. Khanna (Boca Raton: CRC Press), 109-152.

Shewry, P. R., Napier, J. A., and Tatham, A. S. (1995). Seed storage proteins: structures and biosynthesis. Plant Cell 7, 945-956. doi: 10.1105/tpc.7.7.945

Shukla, R., and Cheryan, M. (2001). Zein: the industrial protein from corn. Indus. Crops Prod. 13, 171-192. doi: 10.1016/S0926-6690(00)00064-9

Shyur, L.-F., Zia, K. K., and Chen, C.-S. (1988). Purification and some properties of storage proteins in japonica rice. Bot. Bull. Acad. Sin. 29, 113-122.

Simopoulos, A. P. (2002). Omega-3 fatty acids in wild plants, nuts and seeds. Asia Pacific J Clin Nutr. 11: S163-S173. doi: 10.1046/j.1440-6047. 11.s.6.5.x

Simopoulos, A. P. (2006). Evolutionary aspects of diet, the omega- 6/omega-3 ratio and genetic variation: nutritional implications for chronic diseases. Biomed. Pharmacother. 60, 502- 507. doi: 10.1016/j.biopha.2006.07.080
Taylor, S. L., Remington, B. C., Panda, R., Goodman, R. E., and Baumert, J. L. (2015). "Detection and control of soybeans as a food allergen," in Handbook of Food Allergen Detection and Control, ed S. Flanagan (Woodhead Publishing), 341-366.

Wang, W. (1990). Literature review on duckweed toxicity testing. Environ. Res. 52, 7-22. doi: 10.1016/S.0013-9351(05)80147-1

WHO Technical Report Series 935 (2007). Protein and Amino Acid Requirements in Human Nutrition, 265. Geneva: WHO Press.

Willison, J. H. M., and Davey, M. R. (1976). Fraction 1 protein crystals in chloroplasts of isolated tobacco leaf protoplasts: a thin-section and freezeetch morphological study. J. Ultrastruct. Res. 55, 303-311. doi: 10.1016/S00225320(76)80088-3

Yang, Y., Dai, L., Xia, H., Zhu, K., Liu, H., and Chen, K. (2013). Protein profile of rice (Oryza sativa) seeds. Genet. Mol. Biol. 36, 87-92. doi: 10.1590/S141547572013000100012

Conflict of Interest Statement: The authors declare that the research was conducted in the absence of any commercial or financial relationships that could be construed as a potential conflict of interest.

MC is employed by Hinoman Ltd. and ME consults for Hinoman Ltd.

Copyright (c) 2016 Edelman and Colt. This is an open-access article distributed under the terms of the Creative Commons Attribution License (CC BY). The use, distribution or reproduction in other forums is permitted, provided the original author(s) or licensor are credited and that the original publication in this journal is cited, in accordance with accepted academic practice. No use, distribution or reproduction is permitted which does not comply with these terms. 